\title{
BIOMASS YIELD OF DIFFERENT PLANTS FOR BIOGAS PRODUCTION
}

\author{
Oskars Balodis, Jānis Bartuševics, Zinta Gaile \\ Latvia University of Agriculture, Institute of Agrobiotechnology \\ 2 Liela street, Jelgava, Latvia, LV 3001 \\ Ph: +(371) 28661751, e-mail: balodis.oskars@inbox.lv
}

\begin{abstract}
In order to investigate yield potential of plants probably suitable for biogas production preliminary field trials were carried out at Research and Study farm "Vecauce" in 2010 using eight annual plant species: maize, winter oil-seed rape, oil radish, sunflower, foxtail millet, millet, hemp and amaranth. All species (except oil radish) were represented with several varieties, and some species were harvested at 2-3 development stages. Obtained fresh biomass yield was from 33.05 (millet 'Rudes') till 74.60 (amaranth 'Raudonukai') $t$ ha', but dry matter yield - from 6.98 (amaranth 'Margiai') till 22.05 (winter oil-seed rape 'Excalibur' at GS 85) $t \mathrm{ha}^{-1}$. It was self-evident that biomass yield substantially depended on used species, but also variety influence within the species was relevant. Our data clearly demonstrated substantial $(p<0.05)$ harvest time influence by harvesting winter oil-seed rape and maize at three different times; the highest yield was obtained for rape at GS 85, but for maize - in early October. Studies are only at the initial stage and have to be continued.
\end{abstract}

Keywords: biomass plants, species, varieties, harvest timing, yield.

\section{Introduction}

Suitability of plants' biomass for biogas production is widely investigated in other European countries. As biogas production from agricultural substrates in Latvia has been started only since 2008, we have lack of knowledge about the possibly suitable plants, their varieties, and best growing methods. Plants were investigated mainly for forage production before, but possibility to grow some of them was forgotten at all. Researchers from Western Europe have mentioned two main factors for choice of plant species or materials for biogas production: specific outcome of methane from $1 \mathrm{~kg}$ of organic dry matter, and biomass yield from $1 \mathrm{ha}$. Large part of biogas production success is related to growing technology including choice of proper species and varieties, harvest timing, chopping and ensiling of biomass. Maize (Zea mays L.) is considered as the very suitable plant for using as biogas substrate, but success can not be always guarantied growing only one plant species. Energy crop rotations are practiced in European countries; it means that one energy crop followed by another provides obtaining biomass twice a year, suppress weed growth and save costs. Two plant species can be grown simultaneously, for example maize and sunflower or maize and millet. Such method increases nutrients content and stabilizes crop yield during dry seasons.

The aim of our research was to clear possibility to grow eight different plant species, including untraditional species, for biomass production in Latvian conditions, to compare their biomass yield level, and to start to clarify the main yield determining factors.

\section{Materials and methods}

In order to investigate yield potential of plants probably suitable for biogas production in Latvia field trials of different importance were carried out at Research and Study farm

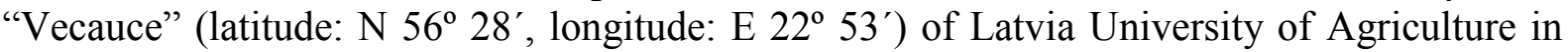
2010. Three trial blocks were established using eight annual plant species: maize (Zea mays) ( 1 st block; 4 replications, 3 harvest dates, four hybrids: 'Tango', 'Celido', 'Ronaldinio', 'Fernandez'), winter oil-seed rape (Brassica napus) ( $2^{\text {nd }}$ block, 4 replications, 3 harvest dates, two varieties: line 'Ovation', hybrid - 'Excalibur'), and preliminary trial in $3^{\text {rd }}$ block with 6 
plant species (was not replicated): oil radish (Raphanus sativus), sunflower (Helianthus annuus), foxtail millet (F. millet further in the text) Setaria italica, hemp (Cannabis sativa), millet (Panicum miliaceum), amaranth (Amaranthus). All species were represented with several varieties (except oil radish - one variety 'Gausiai' was used): sunflower - 'Alussa', 'Alyssa' and 'Pacific'; F. millet - 'Rudukes' and 'Aukses'; hemp - 'Bialobrezskie', 'Felina 32', 'Epsilon 68', 'Benico', 'Santhica', 'Uso 31', 'Futura 75' and 'Fedora 17'; millet 'Gelsves', 'Juosves' and 'Rudes'; amaranth - 'Geltonukai', 'Raudonukai' and 'Margiai'.

Soil in the trials' site was soil-gleyic loam with $\mathrm{pH} \mathrm{KCl}=6.7$ to 7.2 ; content of available for plants K was 146 (winter oil-seed rape $-2^{\text {nd }}$ block) to 190 (maize and other species: $1^{\text {st }}$ and $3^{\text {rd }}$ block) $\mathrm{mg} \mathrm{kg}^{-1}$ and $\mathrm{P}-121$ (winter oil-seed rape $-2^{\text {nd }}$ block) to 232 (maize and other species: $1^{\text {st }}$ and $3^{\text {rd }}$ block) $\mathrm{mg} \mathrm{kg}^{-1}$; humus content 27 to $30 \mathrm{~g} \mathrm{~kg}^{-1}$. Traditional soil tillage with mouldboard ploughing in autumn or month before sowing (winter oil-seed rape) was used in all trials' blocks. Sowing was done according to the described design given in Table 1. Crops were fertilized using a complex mineral fertilizer at the rate of $\mathrm{N} 18 \mathrm{~kg} \mathrm{ha}^{-1}, \mathrm{P} 34 \mathrm{~kg} \mathrm{ha}^{-1}, \mathrm{~K}$ $75 \mathrm{~kg} \mathrm{ha}^{-1}$ before sowing. Top-dressing with nitrogen fertilizer was done twice for maize and winter oilseed rape $\left(70+70 \mathrm{~kg} \mathrm{~N} \mathrm{ha}^{-1}\right)$, hemp and sunflower $\left(70+60 \mathrm{~kg} \mathrm{~N} \mathrm{ha}^{-1}\right)$, and $70 \mathrm{~kg} \mathrm{~N}$ $\mathrm{ha}^{-1}$ for other crops. Sowing rates and dates of all crops are shown in Table 1.

Table 1.

Sowing rate and sowing date of crops

\begin{tabular}{|l|l|l|}
\hline \multicolumn{1}{|c|}{ Type } & \multicolumn{1}{c|}{ Sowing date } & \multicolumn{1}{c|}{ Sowing rate } \\
\hline Maize & 06.05 .2010 & $83300 \mathrm{kernels} \mathrm{ha}^{-1}$ \\
\hline $\begin{array}{l}\text { Winter oilseed } \\
\text { rape }\end{array}$ & 18.08 .2009$. & $\begin{array}{l}\text { line }-80 \mathrm{seeds} \mathrm{m}^{-2} \\
\text { hybrid }-50 \mathrm{seeds} \mathrm{m}^{-2}\end{array}$ \\
\hline Sunflower & 19.05 .2010$. & $83300 \mathrm{seeds} \mathrm{ha}^{-1}$ \\
\hline Oil radish & 17.05 .2010 & $30 \mathrm{~kg} \mathrm{ha}^{-1}$ \\
\hline Setaria italica & 17.05 .2010 & $15 \mathrm{~kg} \mathrm{ha}^{-1}$ \\
\hline Hemp & 17.05 .2010 & $70 \mathrm{~kg} \mathrm{ha}^{-1}$ \\
\hline Millet & 17.05 .2010 & $25 \mathrm{~kg} \mathrm{ha}^{-1}$ \\
\hline Amaranth & 17.05 .2010 & $17 \mathrm{~kg} \mathrm{ha}^{-1}$ \\
\hline
\end{tabular}

Weeds were controlled using herbicides in winter oilseed rape (GS - full emergence) and maize (at 3-5 leaf stage) trials. Butisan star s.c. (metasachlor, $333 \mathrm{~g} \mathrm{~L}^{-1},+$ kvinmerac, $83 \mathrm{~g} \mathrm{~L}^{-}$ 1) $2.5 \mathrm{~L} \mathrm{ha}^{-1}$ was applied for oilseed rape, and Maisters OD 61 s.c. (foramsulfuron, $30 \mathrm{~g} \mathrm{~L}-{ }^{1}$, + natrium metil-jodosulfuron, $\left.1 \mathrm{~g} \mathrm{~L}^{-1}\right) 1.5 \mathrm{~L} \mathrm{ha}^{-1}+$ Estet 600 e.c. $\left(2.4-\mathrm{D}, 600 \mathrm{~g} \mathrm{~L}^{-1}\right) 0.5 \mathrm{~L} \mathrm{ha}^{-}$

${ }^{1}$ was applied for maize. Mechanical weeding was used for $3^{\text {rd }}$ block because of limited availability of herbicides registered for specific species. Insects were controlled by insecticide Fastak 50 e.c. (alfa-cipermetrin, $50 \mathrm{~g} \mathrm{~L}^{-1}$ ) $0.3 \mathrm{~L} \mathrm{ha}^{-1}$ only in winter oilseed rape.

Crops were harvested at different development stages to determine yield $\left(\mathrm{t} \mathrm{ha}^{-1}\right)$ : maize was harvested by special harvester for trials (HALDRUP) with automatic sampler, but other species were harvested by VARI system harvester and average samples for detecting dry matter content $(\%)$ and other quality parameters were taken by hand and after that - chopped and dried. Maize ( $1^{\text {st }}$ trial block) was harvested on 3 September, 17 September, and 4 October. In $2^{\text {nd }}$ block winter oilseed rape biomass was harvested at GS 65 (21 May), GS 79 (21 June), and GS 85 (5 July). Seed and straw yield was determined after harvest (combine harvester HEGE-140) at GS 90-92. Harvest times in the $3^{\text {rd }}$ block: oil radish - at GS 85; sunflower - at GS 80-83; Setaria italica - at GS 75 and GS 85; millet - at GS 75 and GS 85; amaranth - at GS 85; hemp - at 05.08 . 
Dry matter (DM) content was detected by drying samples up to constant weight at $105{ }^{\circ} \mathrm{C}$ and organic dry matter (ODM or VS) was calculated after ashing samples at $550{ }^{\circ} \mathrm{C}$. DM and ODM yield $\left(\mathrm{t} \mathrm{ha}^{-1}\right)$ was calculated. Crude protein was detected by Kjeldahl method (LVS EN ISO 5983-2: 2009), sulphur content - CS-500 analyzers method, and fat content by ISO 6492: 1999 method.

ANOVA procedures and descriptive statistics were used for processing the experimental data. Vegetation period of 2010 characterizes with similar to long-term average temperature and precipitation observations in May and June, but very warm and moist July and August. September was behind warmth conditions observed in long-term period.

\section{Results and discussion}

As so different plant species were used wide range of fresh biomass yields were obtained per all three trial blocks: the highest average fresh biomass yield $\left(62.02 \mathrm{t} \mathrm{ha}^{-1}\right)$ was obtained from rape; it was by $23.56 \mathrm{t} \mathrm{ha}^{-1}$ higher if compared to average yield of millet (38.46 $\mathrm{t} \mathrm{ha}^{-1}$ ) (Fig. 1). Range of average ODM content at harvest of all species per all harvest dates was also wide (from $111.7 \mathrm{~g} \mathrm{~kg}^{-1}$ (sunflower 'Alussa' harvested at GS 83) to $335.2 \mathrm{~g} \mathrm{~kg}^{-1}$ (foxtail millet 'Rudukes' harvested at GS 85). For good quality silage making DM content of plant is very important: if biomass is too wet - additional drying before ensiling can be needed; in other case losses during ensiling can be great. Lower ODM content was noted for sunflower, amaranth and rape at first harvest time, higher values for hemp, millet, foxtail millet, rape and maize at last harvest dates.

ODM yield of investigated plant species varied within a wide range: from $5.81 \mathrm{t} \mathrm{ha} \mathrm{h}^{-1}$ (amaranth 'Margiai' harvested at GS 85) to $21.79 \mathrm{t} \mathrm{ha}^{-1}$ (maize 'Fernandez' harvested at 4 October) and $22.05 \mathrm{t} \mathrm{ha}^{-1}$ (winter oil-seed rape 'Excalibur' at GS 85, Fig. 4). It was evident that harvest timing affected the obtained yield amount. The average ODM yields of all species are shown in Figure 1.

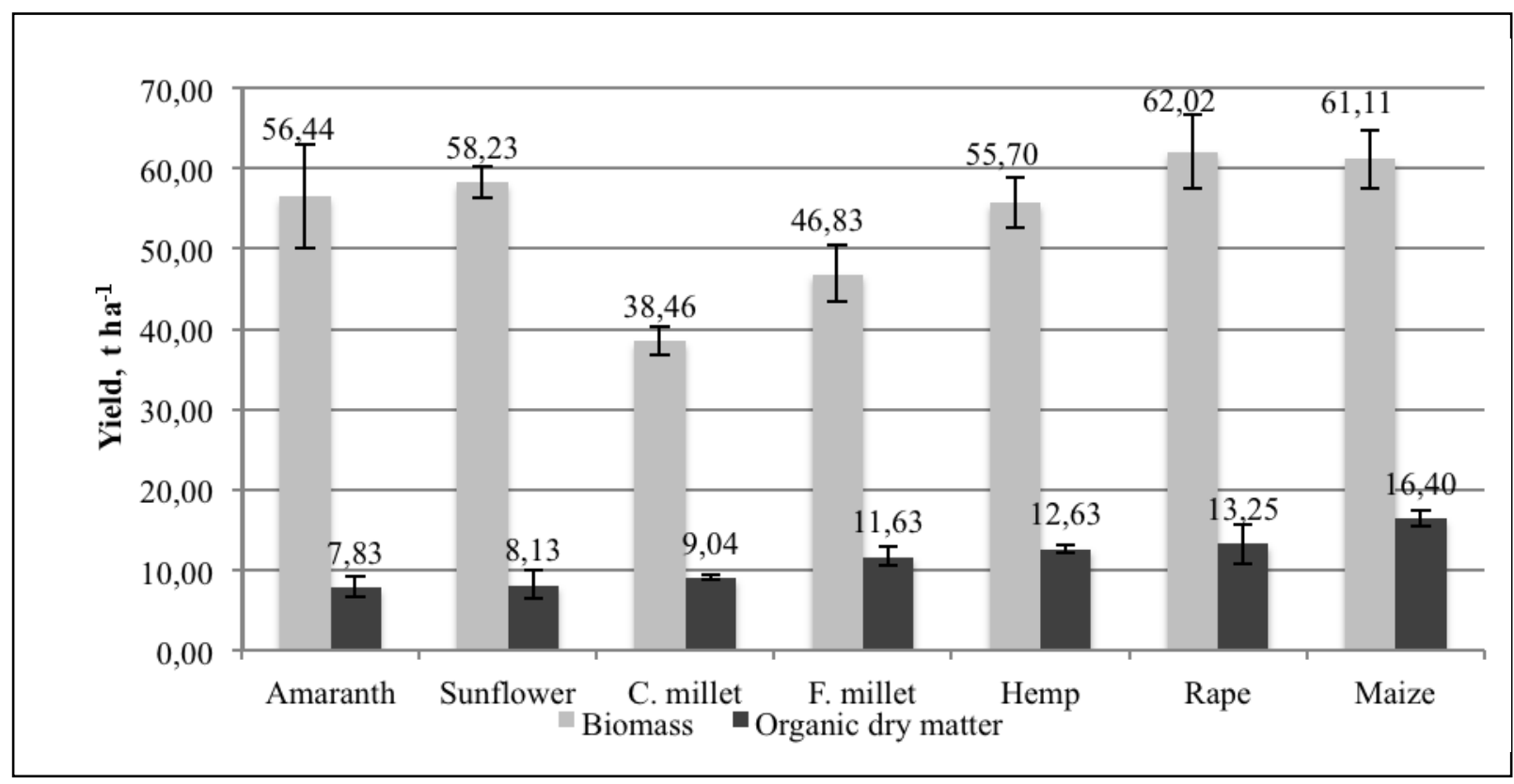

Fig. 1. Average fresh biomass and organic dry matter yield of all species (average from all varieties and harvest dates)

The ODM yield is an important factor influencing biogas and methane yield per unit area. Maize is the main crop used as biogas substrate in Europe due to its very high yield potential from 1 ha [1]. Our investigation showed very high fresh biomass yield of rape (Fig. 1), but 
maize hybrids achieved highest average ODM yield $\left(16.40 \mathrm{t} \mathrm{ha}^{-1}\right)$. Sunflower and amaranth showed $2^{\text {nd }}$ and $3^{\text {rd }}$ highest fresh biomass yields respectively, but at the same time their average ODM yields was lowest: amaranth $-7.83 \mathrm{tha}^{-1}$ followed by sunflower $8.13 \mathrm{tha}^{-1}$. In our research sunflower demonstrated the highest average fat $\left(122.4 \mathrm{~g} \mathrm{~kg}^{-1}\right)$ and protein $(104.8$ $\mathrm{g} \mathrm{kg}^{-1}$ ) content from investigated species. Some authors [1, 2] mentioned that sunflower theoretically can be suitable plant for biogas production due to its high fat content, but empirical research did not approved it. Other researchers, e.g., P. Vindis et al. [3] reported that the highest bio-methane production was achieved using exactly the sunflower substrate (283 $\left.\mathrm{NL} \mathrm{kg}^{-1} \mathrm{VS}\right)$, followed by maize (187 NL $\left.\mathrm{kg}^{-1} \mathrm{VS}\right)$. Also A. Adamovics et al. [4] mentioned high output of methane from sunflower; potential bio-methane yield from unit area is mentioned $2627 \mathrm{Nm}^{3} \mathrm{ha}^{-1}$ for sunflower in agroecological conditions of Latvia.

Amaranth is a crop widely investigated in other countries, also some data on performance of millet and foxtail millet is possible to find. A. Svirskis [5] had mentioned that amaranth, millet, foxtail millet, and some other plant species can be successfully grown for food and fodder in Lithuania's agro-climatic conditions on organic and conventional farms. Two year field trial was carried out during 2006-2007 in Lithuania. The year 2006 was very dry, while 2007 was normal and the yield was higher. Conditions in our investigations in 2010 were even more favorable (very warm season with surplus precipitation) for amaranth and millet, and obtained yield exceeded results in Lithuania (Table 2). Such results propose to continue research with these crops.

Table 2.

Fresh biomass and dry matter yield of amaranth, millet, and foxtail millet
in comparison with data obtained in Lithuania, $\mathrm{t} \mathrm{ha}^{-1}$

\begin{tabular}{|l|l|c|c|c|c|c|c|}
\hline \multirow{2}{*}{ Species } & & \multicolumn{2}{c|}{$\begin{array}{c}\text { 2006 Lithuania } \\
\text { Svirskis, 2009 [5] }\end{array}$} & \multicolumn{2}{c|}{$\begin{array}{c}\text { 2007 Lithuania } \\
\text { Svirskis, 2009 [5] }\end{array}$} & \multicolumn{2}{c|}{2010 Latvia } \\
\cline { 3 - 8 } & Varieties & $\begin{array}{l}\text { FM } \\
\text { yield }\end{array}$ & $\begin{array}{l}\text { DM } \\
\text { yield }\end{array}$ & $\begin{array}{l}\text { FM } \\
\text { yield }\end{array}$ & $\begin{array}{l}\text { DM } \\
\text { yield }\end{array}$ & $\begin{array}{c}\text { FM } \\
\text { yield }\end{array}$ & $\begin{array}{c}\text { DM } \\
\text { yield }\end{array}$ \\
\hline Amaranth & Geltonukai & 34.4 & 4.41 & 27.0 & 7.47 & 50.3 & 7.98 \\
\hline Millet & Rudes & 13.7 & 2.31 & 16.5 & 4.90 & 33.0 & 9.39 \\
\hline Millet & Gelsves & 15.0 & 2.88 & 19.2 & 6.01 & 40.4 & 8.54 \\
\hline Millet & Juosves & 13.3 & 2.04 & 22.1 & 6.80 & 34.1 & 9.90 \\
\hline F.millet & Rudukes & 11.3 & 1.74 & 15.6 & 7,61 & 52.4 & 11.28 \\
\hline F.millet & Aukses & 13.7 & 2.05 & 17.6 & 6,94 & 48.4 & 10.33 \\
\hline
\end{tabular}

P. Vindis et al. [6] reported methane production from amaranth substrate $125 \mathrm{NL} \mathrm{kg}^{-1} \mathrm{VS}$. Amaranth (on average145 mg kg${ }^{-1}$ ) and millet (on average137 $\mathrm{mg} \mathrm{kg}^{-1}$ ) were confirmed as sulphur-richest species in our trial. High content of sulphur can increase hydrogen sulphide concentration in the biogas. Hydrogen sulphide is formed in the biogas plant by the transformation of sulphur-containing protein. Hydrogen sulphide and other sulphur containing compounds must be removed from biogas before it is burned; otherwise there is a risk of corrosion damage to the co-generation unit [7]. Amaranth also demonstrated the highest ash content (139.90 - $\left.167.74 \mathrm{~g} \mathrm{~kg}^{-1}\right)$ in DM from investigated crops. J. Viglasky and J. Huska [8] reported similar ash content (10.17 to $22 \%$ ) of amaranth grown at the Slovak Agricultural University in Nitra. Results of their ash analysis showed that the ash residue contains $1 \mathrm{mg}$ $\mathrm{kg}^{-1}$ of cadmium; $5.05 \mathrm{mg} \mathrm{kg}^{-1}$ of cobalt; $11.28 \mathrm{mg} \mathrm{kg}^{-1}$ of copper; $4.9 \mathrm{mg} \mathrm{kg}^{-1}$ of nickel and $34.3 \mathrm{mg} \mathrm{kg}$ of zinc. Results of the analyses have proved that this plant grown on a polluted field has a high tendency to absorb heavy metals from the soil. It means that amaranth can 
play an important role as a raw material source for industrial biofuel production as well as for environmental protection in this century. B. Pisarikova et al. [9] reported a significant dependence of nutritional value of the above ground biomass of amaranth on the plant growth stage. During plant growth, the nutritional value decreased, which was presented especially by a significant linear decrease of the crude protein content and a significant increase of crude fiber. We have not yet investigated the changes of amaranth chemical composition during maturing.

Hemp (Cannabis sativa) grown in Latvia is mainly well-known as oil and fibre plant. Research of hemp as prospective biomass plant for biomass production is only in the initial stage. The ODM yield of hemp ranged from $10.70 \mathrm{t} \mathrm{ha}^{-1}$ ('Benico') to $14.20 \mathrm{t} \mathrm{ha}^{-1}$ ('Futura 75') (Fig. 2). Swedish scientists [10] did not find significant difference in the specific methane outcome depending on harvest timing (stage of maturity). Harvesting samples on 10 July, 30 July, 4 September and 19 October, 0.25, 0.27, 0.26, 0.23 $\mathrm{Nm}^{3}$ methane per $\mathrm{kg}$ VS respectively was obtained. At the same time biomass yield for the four different harvest times was: 3.6, 6.9, 14.2 and $14.3 \mathrm{tha}^{-1}$ of total DM respectively. The energy yield in the form of methane per hectare was highest at harvest in September and October: 122 and 111 GJ per hectare respectively. The harvest time showed to have little effect on the specific methane yield but a large effect on the biomass yield and thus the methane yield per hectare. A. Adamovics et al. [4] from investigations in Latvia reported similar methane outcome from hemp: $294 \pm 2 \mathrm{~L} \mathrm{~kg}^{-1}$ VS. Potential bio-methane yield from hemp is calculated $3113 \mathrm{Nm}^{3} \mathrm{ha}^{-1}$ [4]. We have challenge for future to investigate the best harvest time for hemp to obtain the highest methane yield per ha.

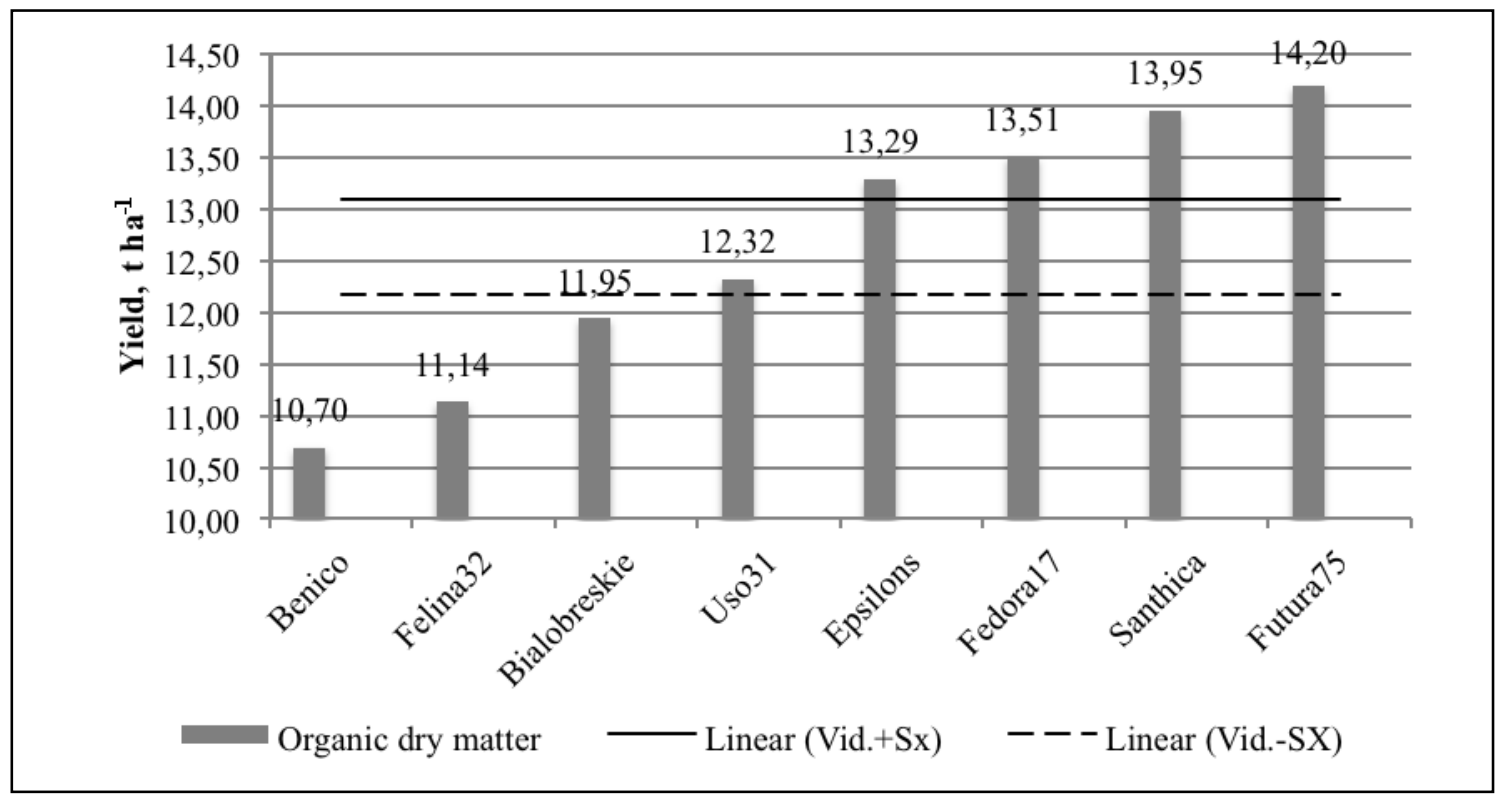

Fig. 2. Organic dry matter yield of hemp depending on used variety.

For obtaining high ODM yields maize has to be harvested as late as possible in Latvian conditions; this is quite well demonstrated in our previously published papers $[11,12,13]$. Also results of current investigation showed that ODM yield increased significantly $(p<0.05)$ during maize development till October. Speaking of other species, only for millet (Fig. 3) marked relevance was not noticed between yields harvested at different dates: ODM yield of variety 'Gelsves' ranged from $7.76 \mathrm{t} \mathrm{ha}^{-1}$ (GS 75) to $9.96 \mathrm{t} \mathrm{ha}^{-1}$ (GS 85) due to maturing, but other two varieties yielded more in earlier stage of maturity. 


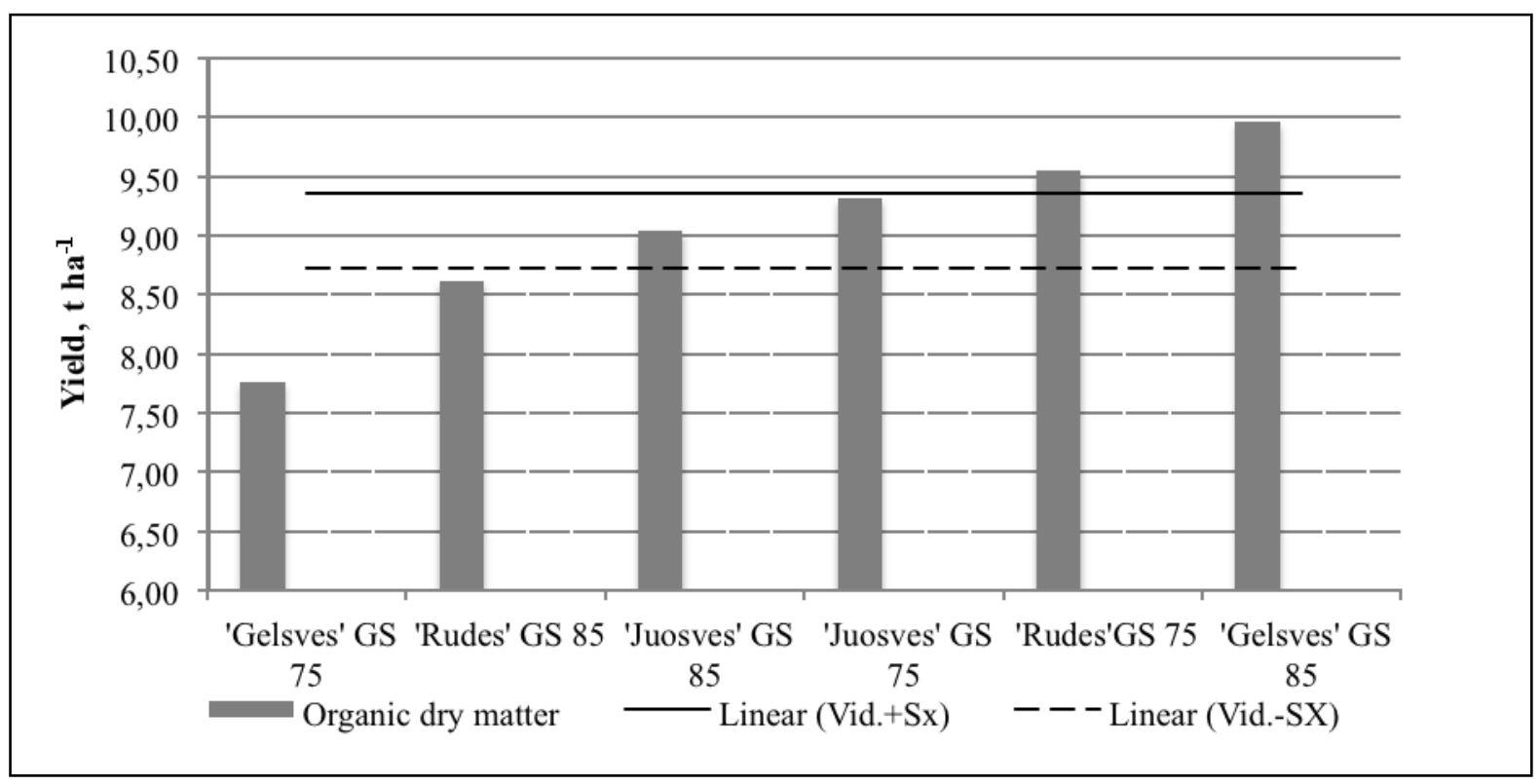

Fig. 3. Organic dry matter yields of millet at different harvest times

Oilseed radish is well-known crop used for green manure in Latvia. It is crop best known for its deep tap root, quick emergence and rapid growth. It is primarily used to break up soil compaction, capture residual nitrogen, and suppress weeds, increase water infiltration, and increase soil biology [14]. Seeds of oilseed radish can contain up to $48 \%$ oil unsuitable for human consumption, but promising as a source of biofuel [15]. This could hence make an interesting biodiesel candidate. Oilseed radish is still unrecognized as bio energy crop; in our investigation we obtained fresh biomass yield $57.8 \mathrm{t} \mathrm{ha}^{-1}$ with DM content $167 \mathrm{~g} \mathrm{~kg}^{-1}$ and DM yield was $9.66 \mathrm{t} \mathrm{ha}^{-1}$. Potential of this plant biomass for biogas production is challenge to investigate during current research also due to its possibility to form high biomass very quickly ( 40-50 days).

Oilseed rape is very interesting crop from different aspects of bio-energy production. It is highly productive biomass crop. Our research showed the highest average fresh biomass yield of rape and the $2^{\text {nd }}$ highest average ODM yield (Fig. 1) from eight investigated species. Significant $(\mathrm{p}<0.05)$ harvesting time impact on biomass yield (Fig. 4) was noted; higher fresh biomass yield was determiner in $2^{\text {nd }}$ harvesting time (at GS 79), but it decreased in $3^{\text {rd }}$ harvesting time (at GS 85). Increased ODM content at later harvesting times was observed and it reached $31 \%$ for 'Excalibur' and 29\% for 'Ovation' at the GS 85 (Fig. 4). Also ODM yield was highest at the last harvesting date (GS 85).

Winter oilseed rape is mainly grown for oil production purposes. Varieties used for food and fodder are low in glucosinolates and erucic acid. Brassica crop species produce a higher quality fuel if compared to other oilseed species due to their relatively low specific qualities in oil [16]. 


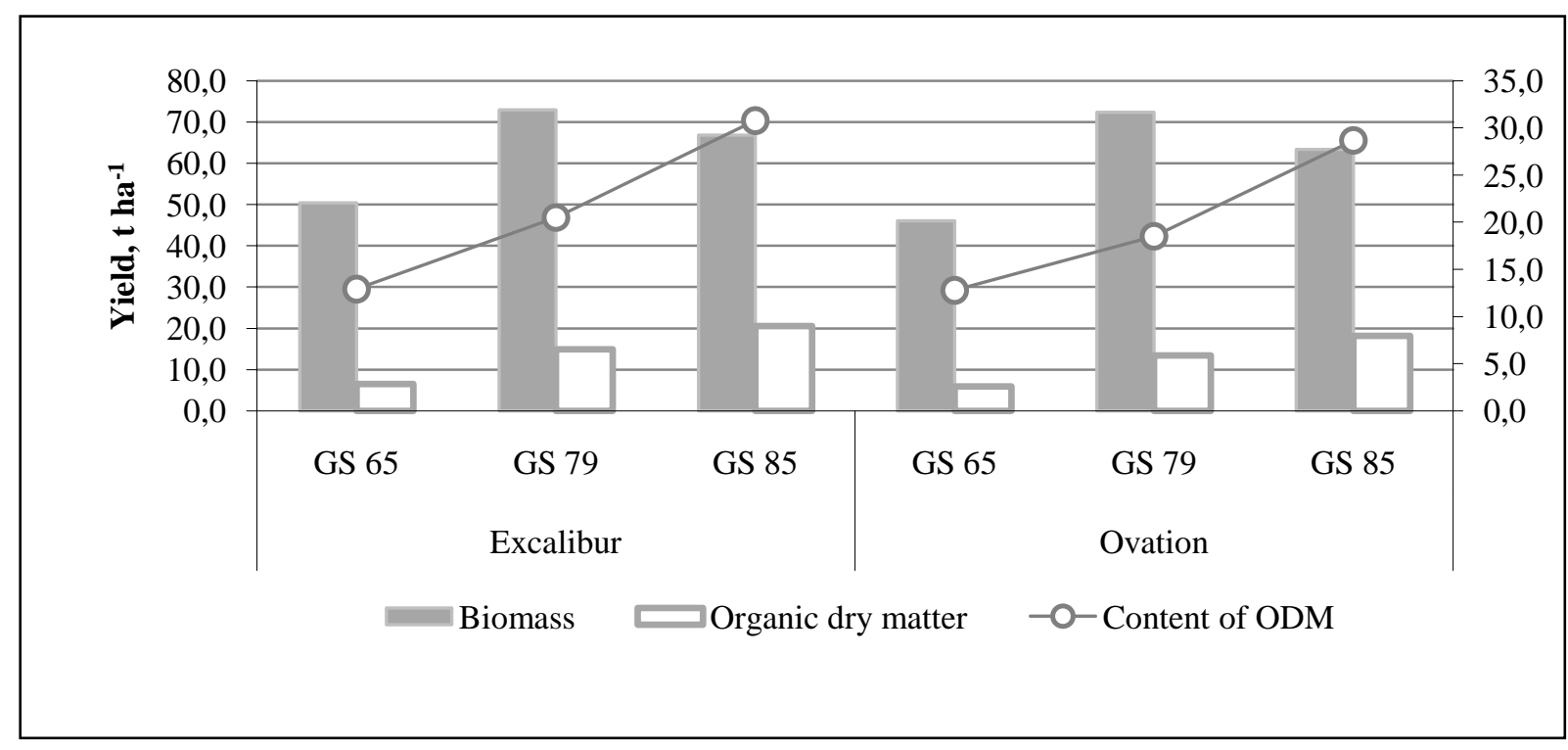

\section{Fig.4. Fresh biomass and ODM yield of winter oil-seed rape and ODM content according to different harvest times and varieties}

Economic seed yields of 3-4 $\mathrm{tha}^{-1}$ are normally produced in Europe [17], we observed 2.5-3.5 $\mathrm{t} \mathrm{ha}^{-1}$ (at favorable agro-ecological conditions - more than $4 \mathrm{tha}^{-1}$ ) in central region of Latvia [18]. High seed yields were obtained also in our experiment, and hybrid variety 'Excalibur' $\left(5.43 \mathrm{t} \mathrm{ha}^{-1}\right)$ gave significantly $(\mathrm{p}<0.001)$ higher yield than line variety 'Ovation' $\left(4.53 \mathrm{t} \mathrm{ha}^{-1}\right)$. Superior straw yield was obtained also from 'Excalibur' $-9.1 \mathrm{t} \mathrm{ha}^{-1}$ (DM content 92\%), but that of 'Ovation' was $7.9 \mathrm{t} \mathrm{ha}^{-1}$ (DM content 91\%). Currently there is no market for oilseed rape straw in Latvia, and almost all of it is chopped and incorporated into soil. Oilseed rape straw is lignocellulose containing agricultural residue that could be used for energy production. Thus oilseed rape seed yield is supplemented with raw materials which can be processed in energy - heat or bioethanol. Lignocellulose is the most abundant organic material on earth and therefore is a promising raw material for bio energy production [19]. Both biogas and ethanol can be produced from the lignocellulosic raw materials. Practically Brassica rapa is used for biogas production and Brassica napus is used as raw material for biodiesel and bioethanol [20]. Results showed considerable energy potential from oilseed rape using seeds for biodiesel production, and straw material for bioethanol and biogas production according to A. Petersson et al. [21].

A further investigation on different ways of oilseed rape usage for energy production purposes has to be developed in Latvia.

\section{Conclusions}

All eight investigated crops gave comparatively high biomass yields, but average organic DM yields above $10 \mathrm{tha}^{-1}$ were obtained from maize $\left(16.40 \mathrm{tha}^{-1}\right)$, winter oilseed rape $\left(13.25 \mathrm{t} \mathrm{ha}^{-}\right.$ $\left.{ }^{1}\right)$, hemp $\left(12.63 \mathrm{t} \mathrm{ha}^{-1}\right)$ and foxtail millet $\left(11.63 \mathrm{t} \mathrm{ha}^{-1}\right)$. Very good meteorological conditions of 2010 for Southern origin plants should be also taken into account using trial data. It was demonstrated that biomass yield substantially depended from used species, but also variety influence within the species was relevant. Harvesting of more matured crop mainly caused significant ODM yield increase (maize, winter oilseed rape); deviation from such tendency was observed for millet. Studies are only at the initial stage and have to be continued, investigating in detail effect of variety and harvesting time on yield amount as well as biomethane outcome from different species. 


\section{Acknowledgement}

Research is founded by ESF project: Contract No. 2009/0225/1DP/1.1.1.2.0/09/APIA/ VIAA/129.

\section{References}

1. Amon, T., Amon, B., Kryvoruchko, V., Machmuller, A., Hopfner-Six, K., Bodiroza, V., Hrbk, R., Friedel, J., Potsch, E., Wagentristl, H., Schriener, M., Zollitsch, W. Methane production through anaerobic digestion of various energy crops grown in sustainable crop rotations. Bioresource Technology, No. 98, 2007, p. 3204-3212.

2. Schittenhelm, S. Chemical composition and methane yield of maize hybrids with contrasting maturity. European Journal of Agronomy, No. 29, 2008, p. 72-79.

3. Vindis, P., Mursec, B., Rozman, C., Cus, F. A multi-criteria assessment of energy crops for biogas production. Journal of Mechanical Engineering, 2009.

4. Adamovics, A., Dubrovskis, V., Plume, I. Biomethane yield from energy plants in Latvia. Proceedings of the 18th European Biomass Conference "From research to industry and markets", Florence: Eta-Florence Renewable Energies, 2010, p. 484-486.

5. Svirskis, A. Prospects for Non-Traditional Plant Species Cultivated for Forage in Lithuania. 2009, Published in internet: http://notulaebotanicae.ro/nbha/article/viewFile/3123/2962

6. Vindis, P., Mursec, B., Rozman, C., Janzekovic, M., Cus, F. Mini digester and biogas production from plant biomass. J. Achiev. Mater. Manuf. Eng., 35/2, 2009, p. 191-196.

7. Koller, J. Treatment of Biogas for Use as Energy. Acta Polytechnica, Vol. 50, 2010.

8. Viglasky, J., Huska, J. Amaranth phytomass for energy and multifunctional uses. Project manuscript; Conference Proceedings; Bio-energy Enlarged Perspectives 10-11 October 2003, Budapest.

9. Pisarikova, B., Peterka, J., Trckova, M., Moudry, J., Zraly, Z., Herzig, I. Chemical Composition of the Above-ground Biomass of Amaranthus cruentus and A. hypochondriacus. ActaVeterinaria, Brno, Vol. 75, Issue 1, 2006, p. 133-138.

10. Kreuger, E., Escobar, F., Svensson, S-E., and Björnsson, L. Biogas production from hemp - evaluation of the effect of harvest time on methane yield. Presented in Poster Session PT01 - Bioenergy 11th IWA World Congress on Anaerobic Digestion, 23-27 September 2007, Brisbane, Australia

11. Gaile, Z., Bartuševics, J. Will maize become an important crop for biogas production in Latvia? Grassland Science in Europe, Vol. 14, 2009, p. 372 - 375.

12. Bartuševics, J., Gaile, Z. Influence of maize hybrid and harvest time on yield and substrate composition for biogas production. Research for Rural Development - 2009, Jelgava, LLU, p. 44 - 49.

13. Gaile, Z. The Role of Maize Harvest Timing for High-quality Silage Production. LLU Raksti, No. 25, 2010, p. 116-128. (in Latvian).

14. Arlauskiene, A., Maikšteniene, S. The effect of catch crop nitrogen on soil properties and spring barley yield. Latvian Journal of Agronomy, No. 10, 2008, p. 78-82.

15. No, S. Y. Inedible vegetable oils and their derivatives for alternative diesel fuels in CI engines: a review. Renewable and Sustainable Energy Reviews, No. 15, 2011, p. 131-149.

16. Kalniņš, A. Possibilities of production and utilization of bio-fuels in Latvia. Rīga, 2005, 167 p. (in Latvian).

17. Rathke, G.-W., Behrens, T., Diepenbrock, W. Integrated nitrogen management strategies to improve seed yield, oil content and nitrogen efficiency of winter oilseed rape (Brassica napus L.): a review. Agriculture, Ecosystems and Environment, No.117, 2006, p. 80-108.

18. Balodis, O., Gaile, Z., Bankina, B. Developments of winter oilseed-rape growing experience in Central Latvia farms. Proceedings of 10th Congress of the European Society for Agronomy. Italian Journal of Agronomy, No. 3, 2008, p. 503-504.

19. Ofori, A., Becker, H. C. Breeding of Brassica rapa for Biogas Production: Heterosis and Combining Ability of Biomass Yield. Bioenergy Research, No. 1, 2008, p. 98-104.

20. Dopako, R., Vega-Nieva, D. J., Ortiz, L. Herbaceous energy crops: reviewing their productivity for bioenergy production. Published in internet: http://193.146.36.56/ence/publicaciones/Valencia_OC7.3.pdf

21. Petersson, A, Thomsen, M. H., Hauggaard-Nielsen, H., Thomsen, A. B. Potential bioethanol and biogas production using lignocellulosic biomass from winter rye, oilseed rape and faba bean. Biomass and Bioenergy No.31, 2007, p. 812-819. 